\title{
MUSUH ALAMI KUTU PUTIH Paracoccus marginatus Williams \& Granara de Willink, (HEMIPTERA: PSEUDOCOCCIDAE) PADA TANAMAN PEPAYA DI MINAHASA UTARA
}

\author{
NATURAL ENEMIES OF MEALYBUG Paracoccus marginatus Williams \& Granara de \\ Willink, (HEMIPTERA: PSEUDOCOCCIDAE) PAPAYA PLANT IN NORTH MINAHASA
}

\author{
Robert W. Tairas, Max Tulung dan Jantje Pelealu*) \\ "Fakultas Pertanian Unsrat Manado
}

\begin{abstract}
The potential of biological control using natural enemies locally has a huge opportunity, therefore, carried out a study in order to determine the types of natural enemies of both predators, parasitoids and pathogens on the mealybug $P$. marginatus live in papaya plants in North Minahasa area. The study found that in Minahasa north, there are natural enemies comprised of predators, pathogens and parasitoids, among others, Chilocorus sp. Scymnus sp. (Coleoptera), Oecophylla smaragdina and some of the family Formicidae (Hymenoptera), earwig (Dermaptera), mites (Acari) and Tetragnatha sp, Tetragnatidae; Plexippus sp. Telamonia sp; Lycosidae (Aranea). At the parasitoid was found only Acerophagus papayae, family Encyrtidae (Hymenoptera), while natural enemies of pathogen is Fungus Keywords : P. marginatus, mealybugs, natural enemies, predators, parasitoid and pathogen
\end{abstract}

\begin{abstract}
ABSTRAK
Potensi pengendalian secara biologi dengan menggunakan musuh alami lokal memiliki peluang besar, oleh karena itu dilaksanakan suatu penelitian dengan tujuan untuk mengetahui jenis jenis musuh alami baik predator, parasitoid dan patogen pada kutu putih $P$. marginatus yang hidup pada tanaman papaya di daerah Minahasa Utara. Hasil penelitian menemukan bahwa di Kabupaten Minahasa utara, terdapat musuh alami yang terdiri dari predator, patogen dan parasitoid, antara lain yaitu Chilocorus $s p$. Scymnus sp. (Coleoptera), Oecophylla smaragdina dan beberapa dari famili Formicidae (Hymenoptera), cocopet (Dermaptera), Tungau (Acari) dan Tetragnatha sp , Tetragnatidae; Plexippus sp. Telamonia sp Salticidae; Lycosidae (Aranea). Pada parasitoid ditemukan hanya Acerophagus papayae, famili Encyrtidae (Hymenoptera), sedangkan musuh alami dari patogen adalah Cendawan Kata kunci: P. marginatus, kutu putih, musuh alami, predator, parasitoid dan pathogen
\end{abstract}




\section{PENDAHULUAN}

Kutu Puth Pepaya, Paracoccus marginatus Williams dan Granara de Willink (Hemiptera: Pseudococcidae), merupakan hama yang merusak tanaman tropis dan merupakan serangga hama polifag pada beberapa komoditas buah-buahan tropis, sayuran dan tanaman hias (Miller and Miller, 2002). Hama kutu putih $P$. marginatus memiliki musuh alami yang terdiri dari Coleoptera, Thysanoptera, Diptera, dan Neuroptera yang bersifat sebagai predator, dan jamur Entomophthorales (Sartiami, 2009). Selain itu ditemukan parasitoid A. papayae (Muniappan, et. al., 2006; Amarasekare, et.al., 2009). Musuh alami merupakan faktor biotik yang berperan penting dalam pengendalian populasi hama. Peranan dan kegiatan musuh alami akan menghasilkan suatu keseimbangan umum yang lebih rendah dari pada yang berlaku apabila faktor tersebut tidak ada. Dalam pengelolaan hama musuh alami dapat berperan untuk menurunkan dan mengatur kelimpahan populasi hama di bawah taraf ambang ekonomi. Musuh alami yang terdiri dari parasitoid, predator dan patogen merupakan pengendali utama hama yang bekerja secara density-dependent, sehingga tidak dapat dilepaskan dari kehidupan dan perkembangbiakan hama. Untung (1993), menyatakan bahwa musuh alami dikenal sebagai faktor pengatur dan pengendali populasi serangga yang efektif karena sifat pengaturannya yang tergantung kepadatan.

Sosromarsono (1985), menyatakan bahwa musuh alami yang terdiri dari parasit, predator dan patogen memegang peranan penting dan biasanya merupakan faktor utama yang mengendalikan populasi hama. Peranan musuh alami dalam pengelolaan hama dapat memberi pengaruh terhadap perkenbangan populasi hama, karena musuh alami secara mandiri dapat mengontrol populasi hama tanpa bantuan manusia. Kelebihan lain dari musuh alami sebagai salah satu komponen pengelolaan hama adalah tidak menimbulkan residu, resurgensi, dan resistensi pada hama target.

Hasil penelitian tahun 2011 menunjukkan bahwa Kutu Putih $P$. marginatus telah menyebar di tiga desa Kabupaten Minahasa Utara, oleh karena itu untuk mendapatkan informasi tentang keberadaan musuh alami kutu putih pada tanaman papaya di Kabupaten Minahasa Utara, maka dilakukan penelitian jenis-jenis musuh alami pada kutu putih $P$. marginatus.

Penelitian ini bertujuan untuk mengetahui jenis jenis musuh alami baik predator, parasitoid dan patogen pada kutu putih $P$. marginatus pada tanaman papaya di daerah Minahasa Utara.

\section{METODE PENELITIAN}

Penelitian dilakukan di dua tempat yaitu di lapangan dan Laboratorium Hama dan Penyakit Tumbuhan, Fakultas Pertanian, Universitas Sam Ratulangi Manado. Kegiatan penelitian dilakukan mulai dari bulan Januari 2012 sampai dengan bulan Maret 2012. Metode penelitian yang digunakan untuk menentukan jenis-jenis musuh alami yaitu dengan cara deskriptif melalui identifykasi musuh alami yang ditemukan pada areal pertanaman papaya,

Pengamatan musuh alami terdiri dari jenis parasitoid, predator, dan patogen.

\section{Jenis Parasitoid}

Pengamatan parasitoid dilakukan dengan mengumpulkan stadia hama (inang) kemudian dipelihara dan diamati setiap hari sampai ditemukan parasitoid. Imago parasitoid yang keluar dikoleksi kemudian diidentifikasi, dengan menggunakan kunci dari (Clausen, 1940).

\section{Jenis Predator}

Pengamatan predator bertujuan untuk mengetahui jenis-jenis predator yang terdapat pada areal penelitian tanaman papaya. Pengambilan sampel secara purposive sampling.

\section{Jenis Patogen pada Serangga}

Penentuan jenis patogen pada hama dilakukan dengan mengumpulkan dan mengamati inang yang terserang. Penentuan jenis patogen dilakukan berdasarkan gejala serangan pada inang dengan kriteria patogen yang disebabkan oleh bakteri, cendawan dan virus (Poinar and Thomas, 1984). 


\section{HASIL PEMBAHASAN}

Hasil penelitian secara deskriptif pada musuh-musuh alami di Kabupaten Minahasa Utara terdiri dari predator, parasitoid dan patogen, dapat ditemukan di lapangan sangat beragam, predator yang ditemukan ada beberapa ordo yaitu ordo Coleoptera, Hymenoptera, Dermaptera Acari dan Aranae. Pada parasitoid ditemukan hanya ordo Hymenoptera pada family Encyrtidae, sedangkan musuh alami dari patogen adalah Cendawan (Tabel 1) .

\section{Predator}

Hasil pengamatan di lapang ditemukan beberapa predator dari famili Coccinellidae terdiri dari dua genus yaitu Scymnus sp. (Gambar 1) dan Chilocorus sp (Gambar 2). Kalshoven (1981), menyatakan bahwa terdapat beberapa jenis predator dari famili Coccinelidae sangat rentan untuk bertahan hidup apabila tidak mendapatkan makanan atau menemukan inang sebagai kelangsungan hidupnya.

Predator sebagai spesies serangga mempunyai ciri-ciri sebagai berikut; dapat memangsa serangga spesies lain, menyerang langsung dan menyebabkan kematian mangsanya secara cepat, dalam menyelesaikan perkembangan hidupnya memerlukan lebih dari satu individu mangsa, larva dan imago predator mempunyai jenis mangsa yang sama, hidupnya bebas dan mempunyai tubuh lebih besar dari pada tubuh mangsanya (Clausen 1940).

Tungau dari Famili Phytoseiidae, Ordo Acari mampu mengendalikan beberapa jenis hama dalam agroekosistem tanaman pertanian. Tungau predator memangsa tungau lain, trips, dan kutu putih. Prilaku menyerang mangsanya, dengan cara menusuk, lalu mengisap bagian dalam tubuh mangsa (Gambar 3).

Tabel 1. Musuh Alami Paracoccus marginatus Berdasarkan Hasil Survei di Beberapa Lokasi di Minahasa Utara

(Table 1. Natural Enemies Paracoccus marginatus Based Surveys in Several Locations in North Minahasa)

\begin{tabular}{llll}
\hline \multicolumn{1}{c}{ Peranan } & \multicolumn{1}{c}{ Ordo } & \multicolumn{1}{c}{ Family } & \multicolumn{1}{c}{ Species } \\
\hline Predator & Coleoptera & Coccinellidae & Chilocorus $s p$. \\
& & Scymnus $s p$. \\
& Aranae & Tetragnatidae & Tetragnatha $s p$. \\
& & Salticidae & $\begin{array}{l}\text { Plexippus } s p . \\
\text { Telamonia } s p .\end{array}$ \\
& & Lycosidae & - \\
& Dermaptera & Labiduridae & Cocopet \\
& Hymenoptera & Formicidae & - \\
Parasitoid & Acari & - & ungau \\
Patogen & Hymenoptera & Encyrtidae & Acerophagus, papayae \\
\hline
\end{tabular}

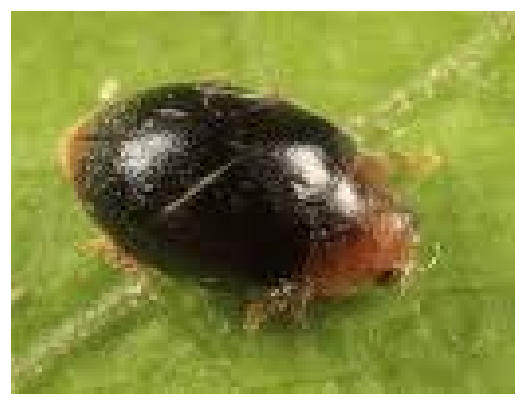

Gambar 1. Imago Scymnus sp

(Figure 1. Imago Scymnus sp) 


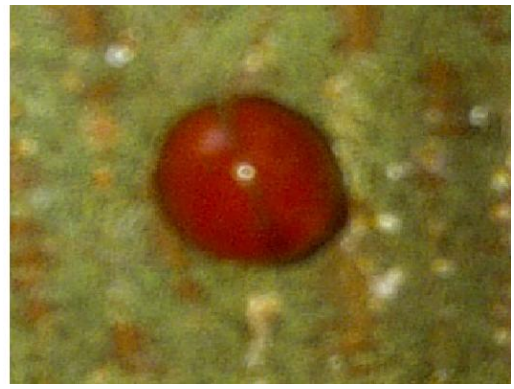

Gambar 2. Imago Chilocorus sp

(Figure 2. Imago Chilocorus sp)

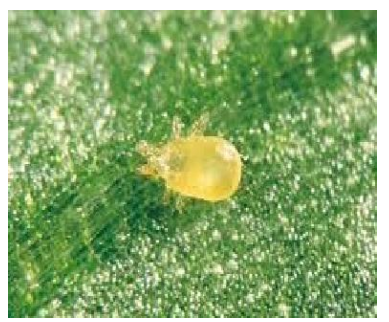

Gambar 3. Tungau

(Figure 3. Mite)

Laba-laba lompat Famili Salticidae, Ordo Araneae bersikap aktif hanya pada siang hari. Laba-laba lompat bermata delapan. Dua mata besar menghadap ke depan, tetapi mata lainnya kecil. Matanya tajam dan bisa melihat mangsanya dari jauh. Laba-laba ini dapat menerkam mangsanya dengan cepat sekali.

Laba-laba Famili Lycosidae, Ordo Araneae umumnya aktif pada malam hari. Labalaba ini tidak membuat sarang, tapi berburu mangsa, sehingga disebut laba- laba pemburu. Serangga yang dilihatnya, dikejar, ditangkap dan digigit/dimakan. Laba-laba biasanya berjalan di atas tanah mencari serangga. Juga berburu di cabang dan dedaunan tanaman. Laba-laba ini memakan ngengat, ulat dan serangga lain. Setelah menangkap serangga, laba-laba menyuntikkan racun yang melumpuhkan korban, kemudian mengisap cairan tubuh korban.

Laba-laba dari Famili Tetragnathidae, Ordo Araneae biasanya membuat jarring dan menangkap mangsanya (Gambar 4). Mata dan kaki laba-laba ini lemah, tidak mampu menangkap mangsa tanpa bantuan jaringnya. Laba-laba jaring bulat menunggu dengan sabar. Ada yang tinggal di tengah jaring, ada juga yang bersembunyi di daun terlipat. Laba-laba lari ke mangsanya hanya bila ada getaran serangga yang terperangkap, kemudian menggigit dan melumpuhkannya. Kadang-kadang langsung mengisap cairan, atau membungkus korban dengan sutera untuk dimakan di lain waktu. Ada jenis berukuran besar dan kecil. Ada yang membuat jaring bulat, ada juga yang membuat jaring dengan bentuk kubah. Ada jenis yang menggunakan jaring yang sama selama beberapa minggu, menunggu di tengah-tengah jaringnya sepanjang hari.

Famili Formicidae (semut); (Hymenoptera) merupakan serangga yang berperan sebagai predator di lapangan banyak ditemukan jenis-jenis semut seperti rangrang (Oecophylla smaragdigna) dan semut hitam (Dolichoderus thoracicus) (Gambar 5).

Famili Labiduridae ordo Dermaptera adalah serangga predator yang biasa dikenal dengan nama cocopet (Gambar 6), organisme ini menyerang dengan cerci (alat penjepit) yang terdapat pada ujung abdomen, aktif mencari mangsa pada malam hari dan bersembunyi di bawah daun (Borror, dkk., 1982). 


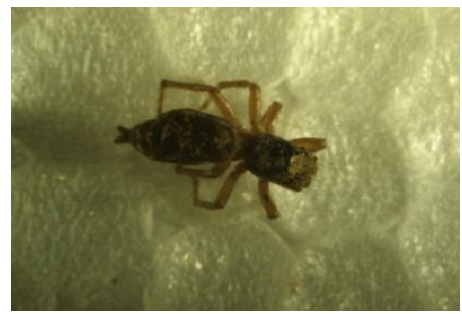

Gambar 4. Imago Plexippus sp

(Figure 4. Imago Plexippus sp)
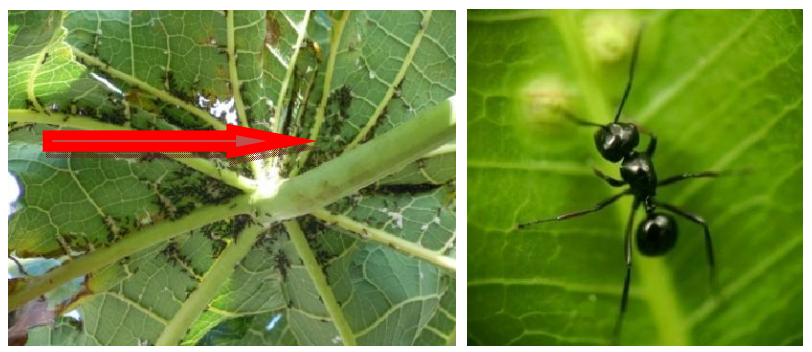

Gambar 5. Semut Hitam yang Sedang Memangsa Kutu Putih (Figure 5. Black Ants were Being Preyed Mealybug)

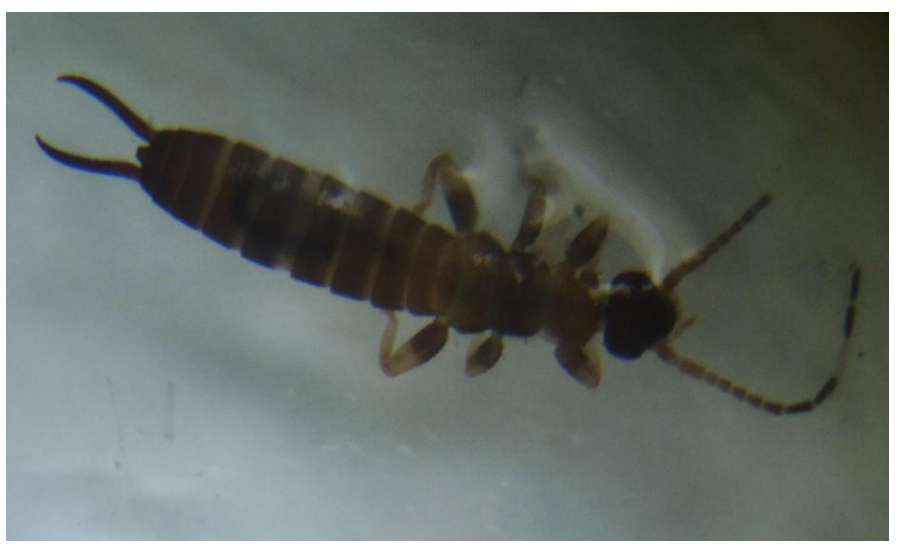

Gambar 6. Labiduridae

(Figure 6. Labiduridae)

\section{Parasitoid}

Hasil pengamatan di lapang bahwa parasitoid yang ditemukan adalah parasitoid Acerophagus papayae yang hidup pada nimfa kutu putih $P$. marginatus. Secara umum, tubuh imago parasitoid berwarna oranye kekuningan dengan sayap yang transparan. Kepala dan antena umumnya berwarna oranye kekuningan serta mata tunggal yang berwarna merah. Toraks umumnya berwarna oranye kekuningan dengan pronotum yang berwarna coklat, sedangkan tungkai berwarna sedikit lebih muda dari pada toraks. Abdomen parasitoid A. papayae umumnya berwarna oranye kekuningan (Gambar 7). Ciri-ciri tersebut sesuai dengan ciri-ciri parasitoid $A$. papayae yang telah di deskripsikan oleh Noyes dan Schauff (2003). Kutu puth Pepaya yang terparasit tubuhnya mengeras atau mengalami mumifikasi berwarna coklat kekuningan (Gambar 8).

Amarasekare (2010), menyatakan bahwa parasitoid A. papayae dapat berkembang pada nimfa kutu putih pepaya instar kedua, nimfa instar ketiga betina dan betina dewasa kutu putih Pepaya. 
Musuh alami yang efektif memiliki ciri-ciri sebagai berikut: mampu mendeteksi populasi hama pada kepadatan yang rendah, memiliki pertumbuhan populasi lebih cepat dibanding dengan hama, menunjukkan laju penekanan populasi hama per kapita cukup tinggi, memiliki fenologi yang sinkron dengan hama target, persisten pada kepadatan populasi hama yang rendah, toleran terhadap berbagai aktivitas pengelolaan tanaman, serta mudah diadopsi petani dan diperbanyak secara massal (Manley, dkk., 2001).

\section{Cendawan}

Hasil pengamatan pada serangga yang terserang patogen belum dapat di identifikasi, namun secara umum dapat dilihat proses terjadinya infeksi pada hama kutu putih. Gejala umum dari serangga yang terinfeksi cendawan adalah adanya pertumbuhan miselium pada kutikel serangga dari nimfa kutu putih. Kemudian lama kelamahan pertumbuhan miselium membungkus seluruh permukaan tubuh (Gambar 9) dan miselium-miseliumnya menembus bagian internal tubuh serangga serta mengolonisasi haemokul. Pertumbuhan miselium diikuti dengan perkembangan spora atau konidia cendawan yang menjadi alat infeksi terhadap serangga. Umumnya serangga yang terserang cendawan biasanya terbungkus dengan miselium berwarna putih, hijau, atau merah (Sembel, 2010).

Hall (1964) dalam Sembel (2010) menyatakan bahwa keberhasilan penggunaan patogen untuk mengendalikan hama serangga tergantung pada biologi dan karakter-karakter serangga inang dan patogen serta lingkungan sekitar. Serangga inang harus hidup dalam suatu habitat yang cocok untuk pertumbuhan dan perkembangan patogen, terutama kelembaban dan suhu (Sulthoni dan Musyafa, 1993).

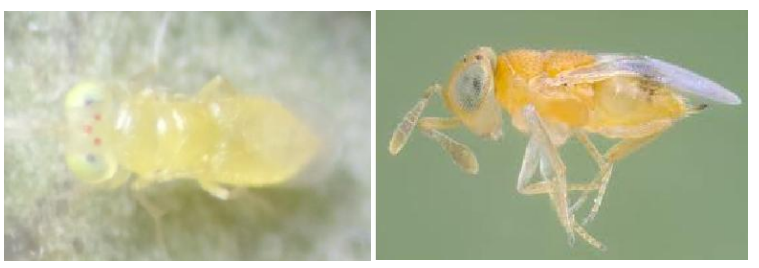

Gambar 7. Parasitoid Acerophagus papayae

(Figure 7. Parasitoid Acerophagus papayae)
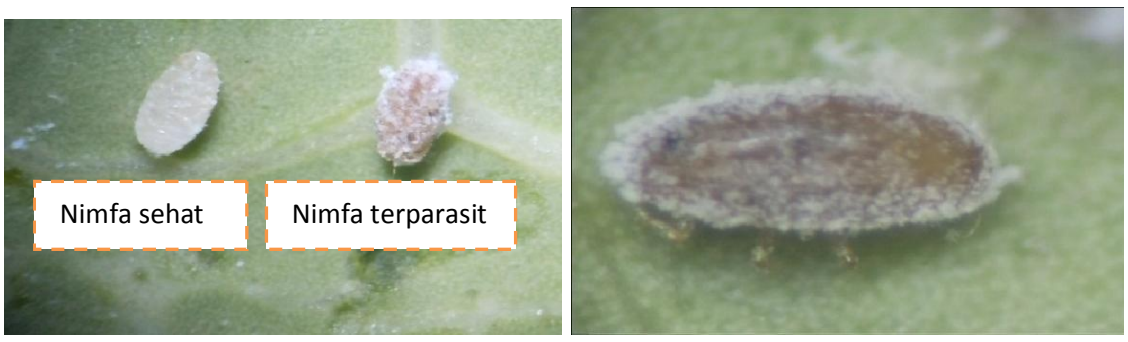

Gambar 8. Nimfa P. marginatus

(Figure 8. Nimfa P. marginatus)

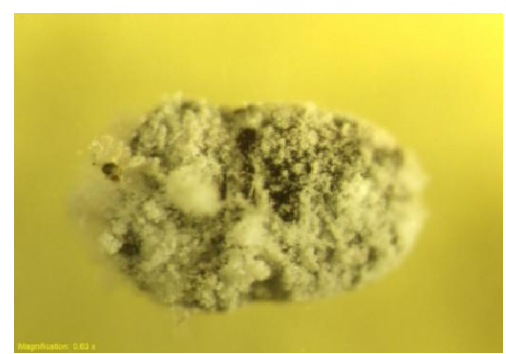

Gambar 9. Cendawan

(Figure 9. Fungus) 


\section{KESIMPULAN}

Musuh alami dari kutu putih yang menyerang tanaman papaya di Minahasa Utara adalah kelompok predator dari ordo Coleoptera famili Coccinelidae yaitu Scymnus sp dan Chilocorus sp., ordo Acari, ordo Araneae famili Salticidae, Lycosidae, Tetragnathidae, ordo Hymenoptera famili Formicidae yaitu Oecophylla smaragdigna dan Dolichoderus thoracicus, ordo Dermaptera famili Labiduridae, parasitoid dari ordo Hymenoptera famili Encyrtidae yaitu Acerophagus papayae dan patogen berupa cendawan yang menutupi tubuh serangga kutu putih

\section{DAFTAR PUSTAKA}

Amarasekare, K.G., C.M. Mannion, and N.D. Epsky. 2010. Host Instar Susceptibility and Selection and Interspecific Competition of Three Introduced Parasitoids of the Mealybug Paracoccus marginatus (Hemiptera: Pseudococcidae). Environ. Entomol. 39 (5) : 1506-1512.

Amarasekare, K.G., J.H. Chong, N.D. Epsky, and C.M. Manion. 2009. Effect of Temperature on The Life History of The Mealybug Paracoccus marginatus (Hemiptera: Pseudococcidae) [Abstrak]. J Econ Entomol Vol.101 hlm: 798-804.

Borror, D.F., C.A. Triplehorn dan N.F. Johnson. 1982. Pengenalan Pelajaran Serangga. Ed. Terjemahan. Gadjah Mada University Press. Yogyakarta.

Clausen, C.P. 1940. Entomophagous Insect. New York : McGraw Hill. 688p.

Fraenkel, G. 1969. Evolution of our thoughton secondary plant substances. Ent Exp and Appl 12:473-486.
Kalshoven, L.G.E. 1981. The Pests of Crops In Indonesia. Van Hoeven, Jakarta.

Manley, D.G., E.C. Murdock, J. Thompson, W.R. James, D.R. King, and R.W. Miller. 2001. Biological Control of Pest4-HIPM Project4Hmanual 136 For Grade Levels 9-12 IPM Level F. Clemson Extension

Miller, D.R. and G.L. Miller. 2002. Redescription of Paracoccus marginatus Williams and Granara de Willink (Hemiptera: Coccidae: pseudococcidae) Including Descriptions of the Immature Stage and Adult Male. Proc. Entomol. Soc. Wash. 104:1-23.

Muniapan, R., D.E. Meyerdirk, F.M. Sengebau, D.D. Berringer, and G.V.P. Reddy. 2006. Classical Biological Control of Paracoccus marginatus (Hemiptera: Pseudococcidae) in the Republic of Palau. Fla. Entomol. 89: 212-217.

Noyes, J.S. and M.E. Schauff. 2003. New Encyrtidae (Hymenoptera) from Papaya Mealybug (Paracoccus marginatus Williams and Granara de Willink) (Hemiptera: Sternorrhyncha: Pseudococcidae). Proc. Entomol. 105(1): 180-185.

Poinar, Jr. G. O. and G. M. Thomas. 1984 Laboratory Guide to Insect Pathogens and Parasites. Plenum Press. New York.

Sartiami, D. Dadang, R. Anwar dan I.S. Harahap. 2009. Persebaran Hama Baru Paracoccus marginatus di Provinsi Jawa Barat, Banten dan DKI Jakarta, in Seminar Nasional Perlindungan Tanaman. Pusat Kajian Pengendalian Hama Terpadu Departemen Proteksi Tanaman Fakultas Pertanian, Institut Pertanian Bogor. 
Sembel, D.T. 2010. Pengendalian Hayati. Hama Hama Serangga Tropis dan Gulma. Universitas Sam Ratulangi. Manado. Penerbit Andi Yogyakarta.

Sosromarsono, S. 1985. Peranan Parasit dan Predator dalam Pengelolaan Serangga Hama. Media Pestisida. Asosiasi Perusahaan Perindustrian Pestisida Indonesia. Jakarta
Sulthoni, A. dan Musyafa. 1993. Pemanfaatan Patogen Serangga dalam Pengendalian Hama Hutan Tanaman Industri di Indonesia. Dalam Proseding Simposium Patologi Serangga I. Yogyakarta, 12-13 Oktober 1993. Kerja sama antara PEI Cabang Yogyakarta. Fakultas Pertanian UGM dan Program Nasional PHT/BAPPENAS.

Untung, K. 1993. Pengantar Pengelolaan Hama Terpadu. Gadjah Mada University Ze Press Cetakan kedua. Yogyakarta. 